\title{
О ПРИЧИНАХ ПОТЕРИ НЕСУЩЕЙ СПОСОБНОСТИ КОМПОЗИТНОЙ БАЛКИ ПРИ ТРЕХТОЧЕЧНОМ ИЗГИБЕ
}

\author{
@ Ф.Р. Шакирзянов, Каюмов Р.А., Паймушин В.Н., Холмогоров \\ C.A.
}

faritbox@mail.ru,kayumov@rambler.ru,vpajmushin@mail.ru,hkazan@yandex.ru

\author{
УДК 539.3
}

DOI: $10.33184 /$ mnkuomsh2t-2021-10-06.99.

\begin{abstract}
Приводятся резултаты экспериментальных и численных исследований задача о трехточечном изгибе композитной балки. При численном анализе поведения балки, которое проводится в физически и геометрически нелинейной постановке, учитывается, что она изготовлена путем склеивания препрегов, уложенных вдоль оси образца. Для определения предельной нагрузки, при достижении которой происходит потеря прочности элементов образца, использован критерий Цая-Ву. Проведен сравнительный анализ поведения композитной балки при различных ее толщинах и различных диаметрах нагружающего ролика. Выявлено, что разрушение коротких балок происходит в результате потери прочности материала под нагружающим роликом (посередине), а в длинных происходит расслоение образцов по адгезионному слою, которое вызывается потерей устойчивости этого слоя по неклассической поперечно-сдвиговой форме. Показано, что диаметр ролика практически не влияет на величину предельной нагрузки, в то время как нагрузка, при которой происходит потеря устойчивости несущего слоя, весьма чувствительна к изменению его величины. Выявлена хорошая корреляция численных результатов с данными, полученными в экспериментальных исследованиях рассматриваемых типов образцов.
\end{abstract}

Работа выполнена в рамках Российского фонда фундаментальных исследований (проект № 19-08-00349) и Российского научного фонда (проект № 19-19-00059).

Шакирзянов Фарид Рашитович, к.ф.-м.н., доцент, КазГАСУ (Казань, Россия); Farid Shakirzyanov (Kazan State State University of Architecture and Engeneering, Kazan, Russia)

Каюмов Рашит Абдулхакович, д.ф.-м.н., профессор, КазГАСУ (Казань, Россия); Rashit Kayumov (Kazan State State University of Architecture and Engeneering, Kazan, Russia)

Паймушин Виталий Николаевич, д.ф.-м.н., профессор, КНИТУ КАИ (Казань, Россия); Vitalii Pajmushin (Kazan National Research Technical University named after A. N. Tupolev - KAI, Kazan, Russia)

Холмогоров Сергей Андреевич, к.ф.-м.н., ведущий инженер, КНИТУ КАИ (Казань, Россия); Sergei Kholmogorov Kayumov (Kazan National Research Technical University named after A. N. Tupolev - KAI, Kazan, Russia) 
Ключевые слова: композит, геометрическая нелинейность, физическая нелинейность, потеря устойчивости, прочность, адгезионный слой.

\section{On the causes of the loss of the bearing capacity of a composite beam in three-point bending}

The results of experimental and numerical studies of the problem of three-point bending of a composite beam are presented. In the numerical analysis of the behavior of the beam, which is carried out in a physically and geometrically nonlinear formulation, it is taken into account that it is made by gluing prepregs laid along the axis of the sample. To determine the ultimate load, upon reaching which there is a loss of strength of the sample elements, the Tsai-Wu criterion was used. A comparative analysis of the behavior of a composite beam for different thicknesses and different diameters of the loading roller is carried out. It was revealed that the destruction of short beams occurs as a result of the loss of strength of the material under the loading roller (in the middle), and in the long beams, the delamination of the samples along the adhesion layer occurs, which is caused by the loss of stability of this layer in a nonclassical shear shape. It is shown that the roller diameter has practically no effect on the value of the ultimate load, while the load at which the stability of the bearing layer is lost is very sensitive to a change in its value. A good correlation was found between the numerical results and the data obtained in experimental studies of the considered types of samples.

Keywords: composite, geometric nonlinearity, physical nonlinearity, buckling, strength, adhesive layer.

\section{Литература}

1. Паймушин В.Н., Каюмов Р.А., Шакирзянов Ф.Р., Холмогоров С.А. О специфике работы композитного несущего слоя трёхслойной пластины при локальном нагружении. Вестник Пермского национального исследовательского политехнического университета. Механика. 2020; (4): 152-164.

2. Паймушин В.Н., Холмогоров С.А. Физико-механические характеристики волокнистого композита на основе углеленты ЭЛУР-П и связующего ХТ118 // Механика композиционных материалов. - 2018. - Т. 54. - С. 5-20.

3. Thomsen O.T. Theoretical and experimental investigation local bending effects in sandwich plates // Composite Structures. - 1995. - Vol. 30 - pp. 85-101.

4. Bonet J., Wood D. Nonlinear Continuum Mechanics for Finite Element Analysis. - Cambridge University Press, 2008. - 318 p. 